\title{
THE 1927 COMMUNIST UPRISING IN SUMATRA: A REAPPRAISAL'
}

\author{
Audrey R. Kahin
}

The Indonesian Communist Party Central Committee, in its meeting at Prambanan in December 1925, called for its members to launch a nation-wide uprising against the Dutch. ${ }^{2}$ This rebellion against colonial rule was initially planned for July of 1926, but disagreements in the ranks of the Communist Party and counter measures by the Dutch government forced its postponement. The Party's former head, Tan Malaka, whom the Dutch had exiled in 1922, was the most outspoken critic of its decision to revolt. ${ }^{3} \mathrm{He}$

\footnotetext{
${ }^{1}$ An earlier version of this article was given as a talk to the Southeast Asia Program at Cornell on February 15, 1996. Research for the article was carried out in 1995 as part of a larger project on the modern history of West Sumatra under a grant from the Social Science Research Council. I wish to thank the Council for their support.

${ }^{2}$ Harry J. Benda and Ruth T. McVey, eds., The Communist Uprisings of 1926-1927 in Indonesia: Key Documents (Ithaca: Cornell Modern Indonesia Project, 1960), pp. 115-16. In this volume, the document entitled "The Course of the Communist Movement on the West Coast of Sumatra," is a translation of Chapter 1 ("De Gang der Communistische Beweging ter Sumatra's Westkust") of the Rapport van de Commissie van Onderzoek, vol. 1 (Weltevreden: Landsdrukkerii, 1928), pp. 1-92. The second chapter of the Commission Report "Oorzaken en Gevolgen van het Communisme ter Westkust," is translated (with some omissions) as "The Development of the Communist Movement on the West Coast of Sumatra," in B. Schrieke, Indonesian Sociological Studies, Part One (The Hague: Van Hoeve, 1955), pp. 83-166.

${ }^{3}$ Ibrahim gelar Datuk Tan Malaka was born probably in 1897 in Pandam Gadang near Suliki, West Sumatra. After attending high school in Bukittinggi he trained as a teacher in Holland. Returning to Indonesia in 1919, he taught first in a plantation in East Sumatra, then moved to Semarang in 1921 where he founded schools based on Communist principles. He succeeded Semaun as chairman of the Indonesian Communist Party (PKI) in late 1921, then was exiled by the Dutch in March 1922, going first to Holland and then to the Soviet Union where in mid-1923 he was appointed Comintern representative for Southeast Asia. He established his headquarters in Canton in December 1923, moving to Manila in 1925, and in 1926 to Singapore. On Tan Malaka, see particularly Harry A. Poeze, Tan Malaka: Levensloop van 1897 tot 1945 (The Hague: Smits, 1976); see also Benedict R. O'G. Anderson, Java in a Time of Revolution (Ithaca: Cornell University Press, 1972), pp. 269-74.
} 
argued that a successful uprising could only be mounted after a period of organized mass action and contended that the Party was heading for a putsch, not a rebellion. Party leaders pushed ahead with their plans, though as the months passed Tan Malaka's messages opposing the rebellion from across the Malacca Straits exerted a growing influence on Party members, particularly in his Minangkabau home region of West Sumatra. Ultimately, however, this was one of only three areas where the rebellion actually broke out in the form of armed conflict, however disorganized, chaotic and unsuccessful-the other two being Banten in West Java and, to a much lesser extent, Batavia itself. ${ }^{4}$ The uprising did not take place in West Sumatra until January 1, 1927, about six weeks after the Dutch government had crushed the rebels in Batavia and Banten.

I propose to examine why West Sumatra was one of the very few places where the rebellion occurred; and to analyze the nature of the opposition to the colonial government there, the causes and course of the revolt, and the extent to which the rebels who participated represented the major thrust of anticolonial nationalism in the region.

\section{Opposition to the Colonial Government}

The Minangkabau, whom the Dutch adviser for Native Affairs, Charles O. van der Plas described as "a restless people with a long tradition of revolt and resistance," had always been proud of this history of opposition to outside forces, whether from Java or from Europe. In fanning discontent in the mid-1920s, Minangkabau revolutionaries recalled the two previous struggles against the Dutch in West Sumatra: the Paderi Wars which raged between 1820 and 1837 as the Netherlands government was first extending its authority over much of the highlands; and the tax rebellion of 1908 , when the rural religious leaders spearheaded protests against Dutch efforts to impose direct taxes on the local people. ${ }^{6}$

In the years preceding 1927 the dynamic which most strengthened the cohesion of anti-Dutch groups in the region was the close interrelationship between Islam, communism, and nationalism, in which local entrepreneurs played the leading role. This coalescence involved the overlapping of the interests and membership of many differing components of society: the trading community (both small traders and largescale merchants), the religious leaders, the teachers and students in the area's many private schools, the farmers, the political activists, and even some of the traditional village authorities. Members of the merchant community, through their ties with people in all strata of Minangkabau society, oiled the wheels of anticolonial activity. But it

${ }^{4}$ On the Banten revolt, see Michael Charles Williams, Communism, Religion, and Revolt in Banten (Athens, Ohio: Ohio University Center for International Studies, 1990). On the brief outbreak in Batavia, see Ruth T. McVey, The Rise of Indonesian Communism (Ithaca: Cornell University Press, 1965), pp. 343-44.

${ }^{5} \mathrm{Ch}$. O. van der Plas, "Gegevens betreffende de godsdienstige stroomingen in het gewest Sumatra's Westkust" (Weltevreden, May 16, 1929), p. 3.

${ }^{6}$ On the Paderi Wars, see Rusli Amran, Sumatra Barat hingga Plakat Panjang (Jakarta: Sinar Harapan, 1981), pp. 385-492; Christine Dobbin, Islamic Revivalism in a Changing Peasant Economy (London \& Malmo: Curzon Press, 1983), pp. 117-225. On the 1908 uprising, see Ken Young, Islamic Peasants and the State: the 1908 Anti-Tax Rebellion in West Sumatra (New Haven: Yale Southeast Asia Studies Monograph 40, 1994). 
was, in particular, their interaction with the teachers and students at the religious schools that had the greatest impact on the local nationalist movement.

In contrast to other parts of the archipelago, most entrepreneurs in West Sumatra were indigenous: virtually all the small traders were Minangkabau, as were a majority of the large-scale merchants, only a few of the most important being Chinese-most of them based in Padang. ${ }^{7}$ These indigenous traders had many grievances. In its efforts to implement its coffee cultivation system during the latter half of the nineteenth century, the Netherlands Indies government had pursued policies aimed at destroying the traditional Minangkabau trading routes which had run to the east coast of Sumatra and across the Malacca Straits to Penang and Singapore. Colonial officials tried to force Minangkabau traders to use the West Coast ports instead, where Dutch authority was most secure. ${ }^{8}$ At the same time they forbade the use of rice as a trading commodity, which had a devastating impact on the balance between production and trade in the region. Although both of these policies were reversed in the first two decades of the twentieth century, the economy and the local trading community were still feeling their impact in the late 1920s. ${ }^{9}$

In Padang and other West Coast ports, indigenous entrepreneurs felt squeezed out by the Dutch protection of European and Chinese traders. Their concern was shared by Muslims in general who felt threatened by the "Ethical" policy, under which the Dutch government was expanding secular Western education so that it was becoming the major vehicle whereby Indonesians could gain access to positions of wealth and influence. Local Muslims saw this policy as part of an effort to undermine Islam and strengthen Christian missionary proselytizing. Resentment of this effort was a major impetus behind the propagation and expansion of the private Islamic schools throughout West Sumatra, which were established on a scale unmatched elsewhere in Indonesia. These schools provided a political matrix for anticolonial ideas.

The networks of religious and other private schools overlapped with the networks of trade. In part this was because many of these schools could survive financially only by carrying out their own commercial activities, so in fact the teachers and students were themselves often also traders, and in addition most of the schools received financial support from the trading community. Their boarding facilities were often used by traveling merchants on their journeys both within West Sumatra and between it and the outside world. 10

After the First World War, opposition to Dutch rule was strengthened by influences coming from beyond, for-either through trade, religion, or education-even the most remote villages in West Sumatra often had ties with other parts of the Indies and some also with the Malay peninsula and with Europe and the Middle East. ${ }^{11}$

\footnotetext{
7 Young, Islamic Peasants, p. 224.

8 Ibid., pp. 228-29; Dobbin, Islamic Revivalism, pp. 218-19.

${ }^{9}$ See Schrieke, Indonesian Sociological Studies, pp. 96-99, where he notes the impact still felt in 1929.

$10 \mathrm{On}$ the links between independent Islamic groups and the commercial classes in the late nineteenth century, see Young, Islamic Peasants, pp. 101-3.

11 There seems little foundation for the assertion in Benda and McVey's introduction to the English translation of Dutch documents on the 1926/27 uprisings, that "The Minangkabau region is an equally good example of a 'closed community' exposed to the disintegrative pressures of the modern world." Benda
} 
In the years leading up to 1927, three towns became the major foci of radical politics and opposition to colonial rule in West Sumatra-Padang Panjang, Silungkang, and Padang. The context of political activity and the character of the movements in each of these three towns were markedly different.

\section{Background to Rebellion}

Padang Panjang, a small, windy town in the foothills of Mount Merapi, with a population in the 1920s of about eight thousand, 12 lies at the upper gateway to the Anai Pass which leads precipitously down from the fertile Minangkabau highlands to the Padang coastal plain. In the early decades of the twentieth century the town was a major crossroads both for traders transporting their goods between the highlands and the West coast, and also for political, religious, and educational ideas arising from within or penetrating from outside the region. The major base of the Communist Party and its People's League (Sarikat Rakyat) in Padang Panjang lay in the innovative modernist religious schools, which had made their first appearance in the early years of the twentieth century, attracting students from throughout the Malay world..$^{13} \mathrm{By}$ the early 1920s many of the younger teachers and students in these non-government schools were radical opponents of Dutch rule and saw no incompatibility in using both Islam and communism in their struggle against Dutch capitalism and political control. ${ }^{14}$

Probably the person who had most influence on the students in these schools was Zainuddin Labai el Junusiah, a teacher at the modernist Islamic Sumatra Thawalib schools, who himself founded the Diniyyah school system in 1915. More radical than his senior colleagues in the modernist (kaum muda) movement, ${ }^{15}$ Zainuddin Labai was very attracted to the teachings of the Cairo modernist Mohammad Abduh and his Syrian disciple, Rasjid Ridha. In fact, Zainuddin has been described as "probably the greatest reader of Said Rasjid Ridha in Minangkabau."16 He was, however, also an

and McVey, Communist Uprisings, p. xx. Recent scholarship, notably that of Christine Dobbin, Jane Drakard, and Ken Young, has shown the number and strength of the contacts of the highlands of West Sumatra with the outside world long before the twentieth century.

12 The 1930 census estimated its population at 6,842 in 1920 and 9,609 in 1930.

13 Hamka, Sedjarah Islam di Sumatera (Medan: Pustaka Nasional, 1950), p. 40.

${ }^{14}$ Schrieke noted that the word capitalism was "'translated' into the Minangkabau language, as kapi, the Minangkabau equivalent to kafir or unbeliever, plus setali, the Dutch twenty-five cent piece." These, then, combined "feelings against the unbelievers, the kapi, and the feelings against . . . the tax-demanding government." Schrieke, Indonesian Sociological Studies, pp. 156-57.

15 The three best known of these were Haji Abdulkarim Amrullah (Haji Rasul), Syekh Mohammad Djamil Djambek, and Dr. H. Abdullah Ahmad. All three had returned to West Sumatra from Mecca during the first decade of the twentieth century and were active particularly in reforming Islamic education. On them, see in particular, Taufik Abdullah, Schools and Politics: The Kaum Muda Movement in West Sumatra (Ithaca: Cornell Modern Indonesia Project, 1971), Deliar Noer, The Modernist Muslim Movement in Indonesia 1900-1942 (Singapore: Oxford University Press, 1973), and Hamka, Ajahku, 3rd printing (Jakarta: Djajamurni, 1967).

${ }^{16}$ H. Abdoelmalik K. A [Hamka], "Saja Teringat," in Boekoe Peringatan 15 Tahoen Dinijjah School Poeteri Padang Pandjang (Padang Panjang: Dinijjah School Poeteri, [1938]), p. 26. Ridha was regarded by some as the "father of Arab nationalism" and has been described as the "most influential Muslim thinker of his generation." See Edward Mortimer, Faith \& Power: The Politics of Islam (New York: Random House, 1982), pp. $247,249$. 


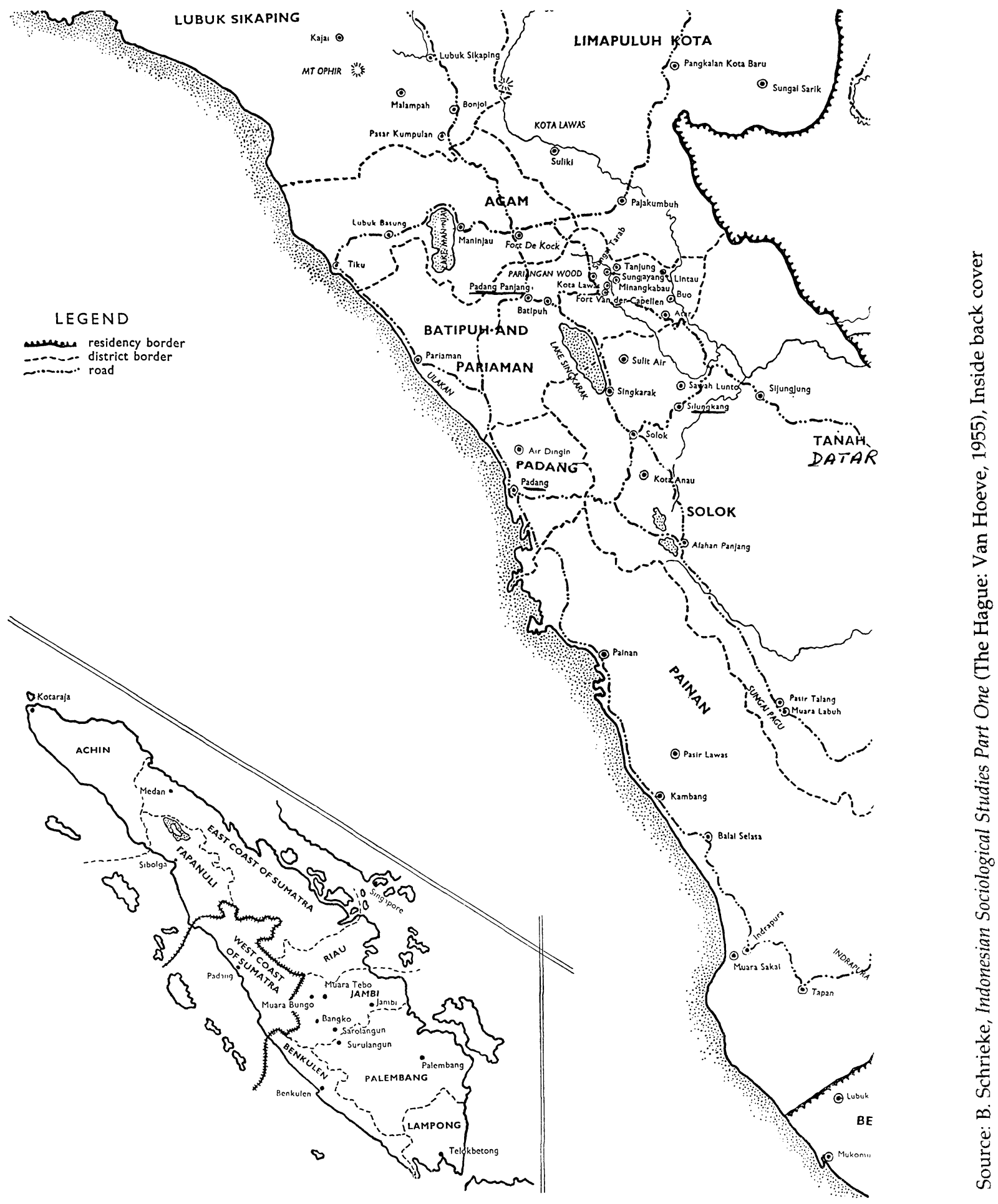

West Coast of Sumatra, 1926-1927 
admirer of Kemal Ataturk, translating his biography and teaching classes aboutKemal's nationalist movement in Turkey. ${ }^{17}$ He refused the offer of a subsidy from the Dutch Assistant Resident to support his school, ${ }^{18}$ and he made no attempt to persuade his students against the radical and Communist ideas to which they were increasingly attracted. In 1918 he had founded Al Munir, an Islamic journal ${ }^{19}$ brought out by his students, which he edited until his death on July $10,1924 .{ }^{20}$ In the early 1920s, journals and newspapers from throughout the Indies came to Al Munir's office, which a former student described as "the most influential meeting place for . . . students [in the private schools], where not only intellectual ideas were spread but friendship, comradeship and unity were strengthened."21

From 1920, the religious schools, especially in Padang Panjang, became places where religion and radical politics overlapped and reinforced each other in the face of opposition from the stubborn and autocratic founder and headmaster of the Thawalib school, Haji Abdulkarim Amrullah (Haji Rasul), who tried to combat what he saw as the atheistic ideas being propagated by his students. Haji Rasul had violent arguments about the Communist ideology with two of his brightest and most radical students and assistants, Djamaluddin Tamin, who later became Tan Malaka's principal lieutenant, and H. Datuk Batuah. ${ }^{22}$

It was H. Datuk Batuah whom the Dutch and most subsequent writers have credited with bringing communism to the modernist schools in West Sumatra after he made a trip to Aceh and Java in the first half of $1923 .{ }^{23}$ In Aceh he met with Natar Zainuddin ${ }^{24}$ and on Java with leaders of the Communist Party, including Haji

17 Hamka, "Saja Teringat," p. 26; Noer, Modernist Muslim Movement, p. 41.

18 Hamka, "Saja Teringat," pp. 24-26. Hamka notes that Abdullah Ahmad's Adabiah school in Padang had accepted such a subsidy. Government subsidies were granted to private schools with qualified teachers who gave at least three hours a day of instruction in such subjects as writing, reading, and arithmetic. "Vereeniging-Vereeniging di Sumatra," Extract from Oetoesan Melajoe, December 1917, No. 243 (Van Vollenhoven Institute Library, Leiden).

19 Meaning, according to Noer, "the Illuminative" and patterned on Al Manar founded in Cairo by Ridha in 1898 and edited by him.

20 Doenia Achirat [Fort de Kock], July 10, 1924. This was the second Al Munir to appear in West Sumatra. A journal of the same name had initially appeared in Padang under the editorship of Haji Abdullah Ahmad. It was written in Arabic characters and was published from 1911-1915 when its printing works were destroyed by fire. Mahmud Junus, "Peranan Surau dan Masjarakat," Paper given at the Seminar, "Islam di Minangkabau," July 23-26, 1969 (stensil, Minang Permai), p. 10.

${ }^{21}$ H. M. D. Datuk Palimo Kajo, "Riwajat ringkas Thawalib Padangpandjang," Paper presented at the ceremony opening a new Asrama and celebrating the 55th anniversary of the Thawalib Padangpanjang, September 11, 1966 (Typescript, in author's possession), p. 9.

22 Hamka, Ajahku, p. 132.

23 See J. Th. Petrus Blumberger, De Communistische Beweging in Nederlandsch-Indië (Haarlem: Tjeenk Willink, 1935), pp. 40-41. Dt. Batuah was born in 1895 in Kota Lawas near Padang Panjang. After graduating from Dutch elementary school, he studied for six years in Mecca (1909-15) before returning to West Sumatra and becoming a pupil of Haji Rasul. He also taught in Kota Lawas. See Hamka, Ajahku, pp. 130-31; Mardjani Martamin et al., Sejarah Kebangkitan Nasional Daerah Sumatera Barat (Jakarta: Dep. Pendidikan \& Kebudayaan, 1977/1978), p. 95.

24 Natar Zainuddin had been born in West Sumatra but taken to Aceh as a child. He had recently worked there as a tram conductor, until the Dutch sent him back to West Sumatra in May 1923 under the government's policy of returning all people they considered dangerous to their home areas. See Benda and 
Mohammad Misbach, an influential member of the Sarikat Islam (Islamic League) in Surakarta, who, when released from jail in 1922, chose to join with the Communist side in the Islamic League split. Clearly it was this Muslim leader who had the greatest influence on Dt. Batuah. According to Takashi Shiraishi, Misbach argued that by choosing the Communist side he was "proving his true Islamness." 25 He explained his position in a Communist Party Congress held in early March 1923:

... basing himself on the Koran, [Misbach] made an argument for several points of agreement between the teachings of the Koran and those of communism. For example, the Koran declares that it is the duty of every Muslim to acknowledge the rights of human beings, and this point also appears in the principles of the communists' program.

Furthermore, it is God's command that [we] fight against oppression and exploitation. That is also one of communism's objectives.

Thus it is correct to say that he who cannot accept the principles of communism is no true Muslim. ${ }^{26}$

These ideas appealed to Dt. Batuah, and on his return to West Sumatra he spread them in the Thawalib school and in Pemandangan Islam, the newspaper he established and co-edited with Djamaluddin Tamin, where they "succeeded in reconciling the 'science of the regulation of the community for the benefit of the masses living in misery and poverty,' with the 'intentions and the requirements of the true Islamic faith!."27 Natar Zainuddin, whom the Dutch sent back to West Sumatra in May 1923, espoused similar ideas in his newspaper Djago-Djago, although its appeal was more openly directed toward the "proletariat." Both journals, however, sought the common ground between Islam and communism in their struggle against capitalism and colonialism. ${ }^{28}$

Whatever influence Dt. Batuah's travels in 1923 may have had on the development of his political ideas, these ideas had already been alive for several years in Padang Panjang. His colleague, Djamaluddin Tamin, had himself joined the Communist Party the previous year, ${ }^{29}$ and, as Tamin noted in his history of the Communist Party, a

McVey, Communist Uprisings, p. 103; and R. Kern, "Politiek Toestand ter Sumatra's Westkust; Instelling Minangkabauraad, Adviz aan G.G. 30 Juni 1924" (Collection Kern: Wd Adviseur Inlandse Zaken [Adviz] 1920-1926 ) [hereafter Kern Collection] (Microfilm 617, Kroch Library, Cornell University), \# 144, pp. 1921.

25 Takashi Shiraishi, An Age in Motion (Ithaca: Cornell University Press, 1990), p. 265.

26 Ibid., p. 261-62. Haji Batuah might well have attended this Congress, and it is noteworthy that the report on Misbach's speech was drawn up by Landjoemin Datuk Toemenggoeng, a Minangkabau agent of the Dutch information service, who would be instrumental in combatting Communist influence in West Sumatra over the next several years.

27 Benda and McVey, Communist Uprisings, p. 103.

${ }^{28}$ Kern, "Politieke Toestand," (Kern Collection \# 144), pp. 21-23. They were not alone in this. Doenia Achirat, published in Bukittinggi [Fort de Kock], also dealt with similar questions, arguing: "Communism does not interfere in religious affairs and every Communist can carry out his own religion. ... As we know, under Islam, one is told to be active among the people. Indeed, the Prophet Mohamad greatly loved the poor. This is the one thing considered most important by communism." Doenia Achirat, May 24, 1924.

29 "Afschrift Proces Verbaal" for Djamaloedin Tamin, December 11, 1932 in Batavia, p. 2. (Mr. 963 geh/33 Algemene Rijksarchief [hereafter ARA]). I am grateful to Takashi Shiraishi for allowing me to copy this document. Born in Kota Gedang near Bukittinggi in 1900, Djamaluddin Tamin had graduated from government elementary school in 1913 and was a founder of the Islamic League (Sarikat Islam) in West 
"Boffet Merah" or Red Canteen had been established by the students in the Padang Panjang schools "five or six months before the Indonesian Communist Party was born in Semarang" in 1920, with Padang Panjang then already known as "the red town in Sumatra." 30

As part of a general crackdown on Communist activity in late 1923, the Dutch sent armed patrols to arrest Datuk Batuah and his colleague, Natar Zainuddin, on November 11, 1923. ${ }^{31}$ Their arrest if anything intensified the burgeoning radicalism among the students and other young people in Padang Panjang and elsewhere in West Sumatra. ${ }^{32}$ Although the Dutch Assistant Resident had argued that once Batuah and Zainuddin were removed, the movement would end, in July of 1924, half a year after their detention, the authorities acknowledged that in West Sumatra "there are now more Communists than before." 33

In Silungkang the roots of the Sarikat Rakyat and the Communist movement were somewhat different from those in Padang Panjang, though students and teachers of the private schools also played a role. However, the basic support and leadership of the Sarikat Islam (Islamic League) and later the Sarikat Rakyat (People's League) in Silungkang came from within the community of small traders tied to the textile industry, together with influences from the railroad workers' organizations and the laborers at the Ombilin coal mine in nearby Sawahlunto.

A small weaving town of about three hundred households, lying in a narrow desolate valley about fifty miles southeast of Padang Panjang, Silungkang was located on the railroad line between Solok and Sawahlunto, and was famous for its textiles throughout the archipelago. Local firms conducted aggressive advertising campaigns, mailing their catalogues to all parts of the Netherlands Indies and even to countries in other parts of Asia and Europe. ${ }^{34}$ Beginning in about 1912 several traders from Silungkang had settled near the Ombilin mine, where to provide services for the government officials, they set up new businesses and opened shops selling textiles and

Sumatra. He had been a teacher and organizer in the Thawalib schools since 1918. See also Tan Malaka, From Jail to Jail, translated and introduced by Helen Jarvis. 3 vols. (Athens: Ohio University Center of International Studies, 1991), 3: 355-56.

30 Djamaluddin Tamim, Sedjarah PKI, Djilid I (typescript, n.d.), p. 10. Emphasis in original. The "Boffet Merah" is also mentioned by H. Datuk Palimo Kajo in his "Riwajat Ringkas Thawalib Padangpandjang," p. 9, and in D. P. Murad, ed., Sungaipuar (Jakartas: Yayasan Sungaipuar, 1966), p. 41.

31 See Doenia Achirat, November 16, 1923, and ibid., November 26, 1923, which lists the other arrests and raids which the government carried out concurrently.

32 Doenia Achirat reports the many protest meetings organized by the Islamic League and the Communist Party over the next few months. Djamaluddin Tamin himself was arrested in December 1923 for articles he published in Pemandangan Islam (probably protesting the arrests of his colleagues). He was sentenced in May 1924 to two years' imprisonment, and spent fifteen months in jail, being released in September 1925. Doenia Achirat, May 10, 1924; "Afschrift Proces Verbaal" for Djamaloedin Tamin, p. 1.

33 "Voorstel om Natar Zainoedin en Hadji Datoeq Batoewah te Interneren, Adviz aan G.G., 23 Juli 1924," (Kern Collection, \# 145), p. 6. It was not until 1924 that the so-called "People's School" (Sekolah Rakyat) was founded in Padang Panjang, modeled after the radical school network first established in Semarang by the Communist leader Tan Malaka, now in exile in the Philippines.

34 A. Muluk Nasution, Pemberontakan Sarikat Rakyat Silungkang Sumatera Barat 1926-1927 (Jakarta: Mutiara, 1981), pp. 45-46. 
other general goods. ${ }^{35}$ The women who wove the cloth, however, stayed home in Silungkang where they formed a cooperative organization for distributing the textiles, one of the women reportedly attending a trade fair in Brussels in 1918 to demonstrate her weaving skill. 36

A local trader, Sulaiman Labai, had established a branch of the originally Javacentered Islamic League in Silungkang in 1914, and he and his followers had close ties with union leaders at the Ombilin mine. One of the young people who would later lead the rebellion in Silungkang, Abdul Muluk Nasution, in his memoir of the period, recalled Labai as "a local intellectual; an expert in the Islamic religion and a skilled speechmaker," and he remembered that "for hours we fascinated young people would listen to his speeches or stories, sometimes about Islam, about politics and sometimes stories from the Thousand and One Nights." 37

Sulaiman Labai became something of a legend in the region. One story recounts how, in 1918, with a few dozen followers, he forced the local stationmaster to surrender two freight cars of rice from a train bound for Sawahlunto which had halted in Silungkang, and he then distributed the food to the hungry people of the town. Before he confiscated the rice, Labai had studied the emergency laws, and he followed them carefully, so the Dutch authorities only had grounds to detain him for a few days before they had to release him with a warning. His bold act attracted many new members to the Islamic League, and when in 1924 its Silungkang branch transformed itself into the Communist-sponsored People's League, most members followed him into the new organization. 38

The principal targets of Dutch repressive activities in that area of West Sumatra were not the Silungkang weavers and traders, but the activists at the nearby Ombilin mine and their political and union organizers, headed by the Sawahlunto branch of the People's League. This branch published two journals which were distributed widely not only in Sawahlunto but in many other towns and villages of West Sumatra and had a readership which expanded to ten thousand after the Dutch arrested the journals' editors in 1924 and 1925. ${ }^{39}$

\footnotetext{
35 Amri Marzali, “Orang Silungkang di Jakarta," (MA thesis, Gaja Mada University, 1973), p. 31.

36 Ibid., p. 35. Nawir Said, Pemberontakan Silungkang 1927 Sumatra Barat (Jakarta: Pentja, 1963), p. 7. See also the entry for "Siloengkang" in the Encyclopaedie van Nederlandsch Oost-Indie, vol. 3 (The Hague: Nijhoff, 1919), p. 774, which in describing the lack of fertile land in the area, writes, "The women weave as a means of subsistence. Alert local women and sympathetic European women have taken the matter in hand and, for example, formed a cooperative organization that buys the material and sells the finished pieces for fixed prices either to traveling merchants or in large markets. So Silungkang has become a well known center of textile art."

37 Nasution, Pemberontakan Sarikat Rakyat, p. 50.

38 Ibid., pp. 47-48. At a special congress held in March 1923, the Communist Party resolved to establish a competing unit wherever a branch of the Islamic League (Sarikat Islam) existed; these new units would be called People's Leagues (Sarikat Rakyat), and would be subordinated directly to the Communist Party (PKI) itself. See McVey, Rise of Indonesian Communism, pp. 155-57.

39 Nawawi Arief editor of Suara Tambang was arrested in February 1924 and Idrus, editor of Panas, and a former Communist leader in Padang, in 1925. Nasution, Pemberontakan Sarikat Rakyat, p. 60; Doenia Achirat, March 5, 1924. According to Mestika Zed, who had access to copies of Suara Tambang, "it not only reported daily news, but also reported on and investigated earlier incidents such as strikes by indigenous workers because of their bad treatment by the foremen of the coalmine there." See Mestika Zed,
} 
Padang, West Sumatra's most important port town, with a population of about $45,000,40$ was the third major center of political activity in West Sumatra. There it was the large-scale indigenous traders who, through their support of schools and social and religious societies, provided the base for development not only of Communist political organizations but of anti-colonial activities in general.

The Entrepreneurs' League (Sarikat Usaha) was founded in Padang in 1914. Its secretary was Mohd. Taher Marah Sutan, "a hard-working idealist" who was a shipping clerk in the port, and its executive body included Sutan Said Ali, who taught at the Adabiah school and was also a writer. ${ }^{41}$ The major impetus behind the League's formation was similar to that of the Islamic League on Java, an attempt by the indigenous merchants in the port city to protect themselves from both Dutch and Chinese trading dominance. ${ }^{42}$ Notable among these Padang merchants was Abdullah Basa Bandaro, a man who, as described by Taufik Abdullah, "maintained good relations with Dutch officials in Padang" and worked closely with Abdullah Ahmad in establishing his Adabiah school. ${ }^{43}$ But Basa Bandaro in the early 1920s was also the principal financial backer of Djago-Djago, Pemandangan Islam, and other newspapers published by the People's League in Padang Panjang. He was one of Tan Malaka's key supporters and the prime conduit for distributing Tan Malaka's works and pamphlets to his followers on Java. ${ }^{44}$ By the early 1920 s the Entrepreneurs' League had become an umbrella organization for political and religious groups inclining toward the politics of Tan Malaka. ${ }^{5}$ In March 1923, Sutan Said Ali left the League to help found the local branch of the Communist Party, but he was soon arrested and spent several months in prison on Java.

Padang was the town that the Indonesian Communist Party (PKI) on Java had targeted as the center for developing communism in West Sumatra. Heading the local Party branch was Magas Abdul Madjid, a young man, born in West Sumatra but with a Javanese mother, who had attended an English school in Singapore and on his return to Java had become active in the Communist movement. In Semarang he met Semaun and other PKI leaders who appointed him official Communist propagandist for West Sumatra. ${ }^{46}$ The Communist branch in Padang initially encountered little success in

"Pemberontakan Silungkang pada Tahun 1927: Suatu Studi tentang Gerakan Sosial di Sumatera Barat" (MA thesis, Gadjah Mada University, 1980), p. 115.

40 Padang's population rose from 38,169 in 1920 to 52,054 in 1930 (about 5 percent were European and about 20 percent Chinese).

41 See Mohammad Hatta, Indonesian Patriot: Memoirs, ed. C. L. M. Penders (Singapore: Gunung Agung, 1981), pp. 32-36 on the influence of Taher Marah Sutan and Sutan Said Ali. Marah Sutan had only been educated up to Grade 5 in primary school, but, in Hatta's words, "was deeply interested in the educational advancement of the young, believing that only scientific and rational knowledge could create responsible citizens." Ibid., p. 32. See also A. A. Navis, "Bank Nasional dalam Sejarah Nasional" (typescript, n.d.), pp. 86-88.

42 Hatta described the League's office as "the meeting place of a number of leaders and intellectuals in Padang." Hatta, Indonesian Patriot, p. 32.

43 See Abdullah, Schools and Politics, p. 25.

44 Tamin, Sedjarah PKI, p. 15.

45 Navis, "Bank Nasional," p. 95.

46 Magas was officially chairman of the People's League. Doenia Achirat, December 5, 1923. He reportedly was paid F40 a month by the PKI. See Toemenggoeng, "Geheime Nota (Kern Collection, \# 146), p. 1; and 
spreading its message. Magas and his young followers "were not taken seriously" and attracted little support. ${ }^{47}$ It was only in early 1924, after the Dutch arrest of Datuk Batuah and Natar Zainuddin and subsequent raids on the houses of other known West Sumatran Communists, that the center of Communist operations moved to Padang. Magas was arrested soon afterwards, and in late 1924 was sentenced to two and a half years in jail. ${ }^{48}$ Sutan Said Ali, who himself had only been released from jail in late 1923, took over the Padang section, and he became the West Sumatran representative to the central Communist Party committee. ${ }^{49}$ Under his leadership the Padang section expanded the number of its members to nearly two hundred by the end of 1925.50

\section{The Course of the Rebellion}

One of the most important incidents influencing the course of the 1927 rebellion was the meeting Tan Malaka headed in Singapore in mid-September 1926, when he and his colleagues decided formally to repudiate the call by the Indonesian Communist Party on Java for an armed uprising. ${ }^{51}$ Aware by that time that the plans for the rebellion would go ahead despite his opposition, Tan Malaka sent orders to his followers in West Sumatra that they should flee the region, as when the rebellion failed, he anticipated that the Dutch would move to suppress the Communist movement as a whole. Responding to the order, many Communists and other radicals, particularly from Padang Panjang and the surrounding area, fled to other parts of Sumatra and across the Malacca Straits. ${ }^{52}$ The Communist Party members who remained were torn between their loyalty to the Communist organization on Java, which was calling for rebellion, and the conflicting orders they were receiving from Tan Malaka. This issue split the Communist Party section in Padang, which had close ties with the Java-based

“Politieke Toestand ter Sumatra's Westkust: Instelling Minangkabauraad. Adviz. aan G.G. 30 Juni, 1924 (Kern Collection \# 144), p. 18. Other leaders of the Padang section were A. Wahab (secretary), Hamzah, K. W. A. Wahab (a Javanese), and Kaharoedin. (Ibid.)

47 "Nota voor den Adviseur voor Inlandsche Zaken: De jongste gebeurtenissen ter Westkust van Sumatra," signed L.d. Toemenggoeng (n.d.) (Kern Collection \# 148), p. 8.

48 He was arrested on March 7, 1924 and sentenced in November. Doenia Achirat, March 12, November 10, 1924.

49 Ibid., November 26, 1923.

50 Benda and McVey, Communist Uprisings, p. 99. According to PKI records, toward the end of 1925, the Padang section had 190 members, Padang Panjang 38, Silungkang 19, Solok 25, and Sawah Lunto, 13. Ibid., p. 106, n. 21.

51 Tan Malaka had arrived in Singapore from Manila in June 1926. Ibid., p. 155.

52 Among those who fled to Singapore in response to Tan Malaka's instructions were Djamaluddin Ibrahim, M. Yatim Latif, and Amir Khan, head of the International Scouting Organization (Internationale Padvinders, IPO); Rivai Junus, who was also an IPO leader, was sent by his parents to study in Cairo; two other young radicals, M. Yunus Kotjek and Asaduddin Kimin, fled to western Aceh, while Alibin, the headmaster of the Sekolah Rakyat in Padang Panjang, hid on a Dutch plantation in Deli. Djamaluddin Tamin after his release from jail had gone to Singapore, and Mahmud, his successor as head of the People's League in Padang Panjang followed him there in mid-1926. According to Leon Salim, another young radical and pupil at the Sekolah Rakyat, at least thirty Communist and other radical leaders then fled to Malaya or Singapore. He himself was able to remain in hiding in West Sumatra and evade Dutch detection as at the time he was only fourteen years old and small for his age. Interviews with Leon Salim, Jakarta 1985, Payakumbuh, 1995, and with H. Rivai Junus, Padang, June 24, 1976. M. Junus Kotjek \& Leon Salim, "Pergerakan Pemuda di Minangkabau," (typescript, 1962), pp. 2-3. 
party, from that in Padang Panjang, which was more strongly influenced by Tan Malaka and his followers.

Throughout 1926 tension was growing in the region, and terrorist actions broke out sporadically. Already in April there were assassinations in Lubuk Basung and Maninjau. ${ }^{53}$ In August, the subdistrict head of Sicincin was killed, ${ }^{54}$ and in September, an adat head was murdered in Kamang and a village head was shot in the Solok area. ${ }^{55}$ In response, Dutch authorities accelerated their round-up of suspected Communist leaders. Padang head Sutan Said Ali was detained while visiting Medan in May, and on October 13 the Dutch arrested the Silungkang leader, Sulaiman Labai, and his principal lieutenant, Dt. Bagindo Ratu. ${ }^{56}$

The new head of the Party's Padang Panjang branch was Arif Fadlillah, who took up the post in July 1926 after his two predecessors had joined Tan Malaka in Singapore. ${ }^{57}$ Fadlillah attended Tan Malaka's mid-September conference there, and after his return to Padang Panjang led the opposition to mounting a rebellion in West Sumatra. The Communist Central Committee on Java had sent an envoy, Baharuddin Saleh, to West Sumatra in early October to propagate their new plan, and he found that despite the reluctance of the leaders in Padang Panjang, the sections in Padang and also Silungkang were willing to go along. This situation changed, however, when Suleiman Labai was arrested in Silungkang, after which most of his inexperienced successors were reluctant to move without the acquiescence of Fadlillah in Padang Panjang. Because of Fadlillah's continued opposition to the rebellion, the Silungkang leaders decided to await the outcome of events on Java before undertaking any independent actions. ${ }^{58}$

The Communist Party section in Padang, however, was still eager to go ahead with the rebellion. Whein the section was reorganized on October 20,1926, one of the leading activists in West Sumatra, Muhammad Nur Ibrahim, took over its leadership. ${ }^{59}$ Preparations were thrown into further turmoil, however, when on November 14 he too was arrested. At the same time, the Dutch seized the notebooks in which Nur Ibrahim

53 Zed, "Pemberontakan Silungkang," p. 104. He also mentions assassinations in May in Bukit Batabuh, Biaro Gadang and Gadut.

54 Anon, "Militaire memorie van het patrouillegebied Padang" [1928], Memories van Overgave, KIT Collectie 786, ARA.

55 Benda and McVey, Communist Uprisings, pp. 11, 150.

56 Ibid., p. 159. On October 23, the head of the Sarikat Rakyat in Sawah Lunto, Haji Bahaudddin was arrested. Nasution, Pemberontakan Sarikat Rakyat, p. 91.

57 He succeeded Djamaluddin Tamin and Mahmud, now both in Singapore. He was initially assisted by Djalaluddin Ibrahim until he too left the area to join his colleagues in Singapore. Fadlillah had been active in Padang Panjang since at least 1923, when he had been frequently detained by the authorities because of articles he published in Djago-Djago. He had spent six months in jail in 1924. Doenia Achirat, November 26, 1923, February 27, May 10, 1924.

58 Benda and McVey, Communist Uprisings, pp. 165-66.

${ }^{59}$ He was chairman of the local executive of the West Sumatra Sarikat Rakyat between September 1924 and February 1925 and was also reportedly active in obtaining weapons from Alimin and Muso in Malaya. He had been a fugitive from the Dutch since November 1925. See ibid., pp. 104, 120, 150. 
had laid out his plans for the uprising, and on the basis of these the government was able to round up about twenty other leading activists. ${ }^{60}$

The rebellion had broken out in Batavia and Banten on November 12, and the West Sumatra Communists learned from the newspapers that the Dutch had speedily crushed the rebels in Batavia, but that fighting was continuing in Banten. By this time they were also well aware that most of their own top leaders had either been arrested or had fled the region. Nevertheless, at a meeting in Silungkang on December 20 they tentatively decided to go ahead with the rebellion, in part because of threats from one of the participants, Kamaruddin gelar Manggulung, described by the Dutch as "the most infamous gambler in Silungkang,"61 and by an Indonesian account as a "patriotic youth," 62 who dominated the meeting, flourishing a revolver and declaring that it was the duty of the members to act. While holding out few hopes that a general rebellion would succeed in West Sumatra, the meeting declared that, as the Silungkang branch was the strongest in the region, "there was a possibility that if the members [there] acted, then those in other branches would follow and join the uprising." 63 The more reluctant participants took comfort in the fact that two Indonesian soldiers from the Dutch garrison in nearby Sawahlunto were part of their group. ${ }^{64}$ These two assured the meeting that at least twenty of their Indonesian comrades in the garrison would rally to their side when the revolution broke out. 65

Still hesitant, the Silungkang branch made a final effort to get approval from Arif Fadlillah in Padang Panjang. The messenger they sent, however, on discovering that the Dutch had in fact arrested Fadlillah on December 28, immediately fled abroad instead of informing his Silungkang comrades, who were left in ignorance of this further setback. ${ }^{66}$

The Silungkang meeting had drawn up a plan designating the nearby industrial town of Sawahlunto as the major center of the rebellion and midnight of January 1, 1927 as the time for it to be launched. One contingent of the rebels was to bomb both the town's police commissariat office and the dance hall where they believed government leaders and Dutch officials of the Ombilin mine would be celebrating the

60 Ibid; Anon, "Militaire memorie," pp. 18-19.

${ }^{61}$ Benda and McVey, Communist Uprisings, p. 176.

62 Said, Pemberontakan Silungkang, p. 33.

63 Nasution, Pemberontakan Sarikat Rakyat, pp. 94-95. Although the broad outlines of this account are similar to that presented in the Dutch report, it focuses specifically on Silungkang and takes less into account activities in other parts of West Sumatra.

${ }^{64}$ According to Nasution these were Pontoh and Rumuat, whom the committee investigating the uprising described as a corporal who had been expelled from the army because of Communist leanings on July 3 , 1926, and had since then been conducting Communist propaganda among the police. Benda and McVey, Communist Uprisings, p. 161.

65 Nasution, Pemberontakan Sarikat Rakyat, p. 96. The garrison consisted of thirty-one men, of whom twentyseven were Indonesians, all of whom according to Pontoh had become members of the Sarikat Rakyat. Ibid., p. 98.

${ }^{66}$ Benda and McVey, Communist Uprisings, p. 171. The Alimin (Limin) who was sent as a messenger should not be confused with the major Communist Party leader Alimin Prawirodirdjo, who had been arrested with Muso in Johore by the government of the Straits Settlements on December 18. From May of 1926 Limin had been the major contact between Arif Fadlillah in Padang Panjang and the Silungkang section. Ibid., p. 121. 
New Year. At the same time the rebels' military sympathizers were to seize the Sawahlunto garrison and prison, freeing all political prisoners and arresting Dutch officials. By this time they would be joined by bands converging from the surrounding villages, who then would be armed with weapons seized from the garrison. The next morning a giant demonstration was to be held in Sawahlunto, attended by the mineworkers and all the local people, demanding independence from the Dutch. In the meantime, rebels remaining in Silungkang would move against local officials of the Dutch administration and seize their weapons. It was hoped that these combined actions would spark revolts by the Communists in other parts of Sumatra, and eventually reignite the rebellion on Java. ${ }^{67}$

The plan was doomed before it began. Many of the rebels hesitated, still anticipating some word from Arif Fadlillah in Padang Panjang and unaware that he was now in jail. But far more devastating was the fact that, unknown to them, the Dutch had been alerted to part of the plan, and two days earlier had already arrested the two rebel supporters from the Sawahlunto garrison and twenty of their military comrades. The critical actions planned for Sawahlunto, then, never took place.

The rebellion broke out in about eighteen villages (nagari) around Silungkang. ${ }^{68}$ Bands from Silungkang and some of the other villages made their way to Sawahlunto. En route, the first group from Silungkang marched past government army barracks at Muara Klaban, apparently blind to the fact that the guards, on seeing such an armed procession, would inform their colleagues in Sawahlunto that they were about to be attacked. ${ }^{69}$ The Dutch were then able not only to suppress the rebels in Sawahlunto but also snuff out the attack mounted by rebel sympathizers within the Muara Klaban barracks before it began. Most of the main rebel group advancing on Sawahlunto fled in panic when they realized that their plans were in disarray, and several were rounded up by the Dutch and taken to their headquarters in Sawahlunto. The leader of the band, Abdul Muluk Nasution, was arrested and, when dragged into the district office at Sawahlunto, was confronted by the highest indigenous official there, Roesad Dt. Perpatih Baringek, who was brandishing an unsheathed sword and punctuated his interrogation of Abdul Muluk with blows and kicks. (Ironically, Dt. Perpatih Baringek was the elder brother of the leader of the Communist uprising in Batavia, Dahlan, who had been arrested there and was later exiled to the new internment camp at Digul in West Irian where he died trying to escape. ${ }^{70}$ )

67 Nasution, Pemberontakan Sarikat Rakyat, pp. 98-99.

68 These were in addition to Silungkang: Siaro-aro, Air Luo, Sepajang, Sijantang, Tarung-tarung, Padang Sibusuk, Pemuatan, Kampung Baru/Batu Menjulur Sehat, Kabun, Sijunjung, Sungai Batung, Sariek Laweh/Lubuk Torok, Tanjung Balik/Sangiso, Padang Laweh, Pianggu, Tak Boncah, and Tanjung Ampolu. Said, Pemberontakan Silungkang, p. 25. See also, "Overzicht der Communistische Onlusten op Java en ter Sumatra's Westkust sedert Nov. 1926," Pt. 2: “Overzicht der onlusten welke ter Sumatra's Westkust zijn voorgevallen," pp. 9-12, dated May 1927. Indisch Archief (IA70) ARA .

69 Abdul Muluk Nasution was leading this band. See Nasution, Pemberontakan Sarikat Rakyat, pp. 100-101. See also "Overzicht der onlusten," p. 9. According to this report, the rebel leaders informed the guards at Muara Klaban that they were on their way to catch fish.

70 Interview with Leon Salim, September 4, 1995. Rasjid - 70 (Jakarta: Panitia Peringatan Ulang Tahun Mr. Rasjid Ke-70, n.d.), p. 8. On Dahlan, see also McVey, Rise of Indonesian Communism, pp. 340-42. 
Unaware of the flight of the main rebel contingent, two smaller groups from surrounding villages converged on Silungkang, riding in cars and buses flying red flags. They were met by government fire and then taken into custody. ${ }^{71}$ Near a railway bridge at Padang Sibusuk, a rebel force of about sixty to seventy men, headed by "General" Abdul Munap, attacked one of the road convoys bringing reinforcements from Fort de Kock and killed its Dutch commander. ${ }^{72}$

The most bloody actions took place in Silungkang itself. There, the arrest or detention of Suleiman Labai and other senior leaders had left the radical forces under control of inexperienced young people and a motley collection of ruffians and bandits. The rebels killed the Dutch foreman of the Department of Public Works, Mr. Leurs, seizing arms from his warehouse. ${ }^{73}$ Personal vendettas were settled as the Village Head of Silungkang was killed by his own nephew, and rebels also executed some school teachers, lower officials of the agricultural service, two or three goldsmiths, and a railroad employee, a total of about twenty-four people. ${ }^{74}$

Scattered skirmishes and assassinations continued for days and in some places for weeks. In the coastal area around Padang and Pariaman, and in Agam and other parts of the highlands, village heads were still the main targets for assassination. ${ }^{75}$ The Dutch responded in kind, killing at least a hundred of their Indonesian opponents and rounding up thousands of suspects. ${ }^{76}$ Of the total of about three thousand who were actually arrested, several hundred were released after initial interrogation, but by August 1927, the Dutch reported that 1,363 Communists had either been tried or were awaiting sentencing by the court at Sawahlunto alone. ${ }^{77}$

Three of the leaders were sentenced to death, including the Silungkang gambler Kamaruddin Manggulung, and were hanged at the Durian jail in Sawahlunto. ${ }^{78}$ Trials

71 "Overzicht der onlusten," p. 10.

72 The commander was Lt. [W. F. H. L.] Simons, who was killed by a bullet to the heart. Telegram from Padang dated January 3, 1927, signed resident Arends, $M r .24 \mathrm{x} / 27$ and "Relaas van het voorgevallene in den nacht van 2 op 3 Januarie 1927," signed Duboureg, January 7, 1927, Mr. 197/27. See also Said, Pemberontakan Silungkang, p. 27, who states that Munap went on to help the rebel forces at Silungkang, where he was killed. According to Abdul Muluk Nasution, who was a relative of his, Abdul Munap had been a teacher in the government school in Tanjung Ampalu as well as a member of the People's League. Nasution, Pemberontakan Sarikat Rakyat, pp. 115-16.

73 The interrogation of the accused killers of Mr. Leurs appears in "Pemeriksaan Landraad Sawahloento terhadap beberapa orang pesakitan," reproduced in Zed, "Pemberontakan Silungkang," pp. 171-86.

${ }^{74}$ For a list of those killed, see Benda and McVey, Communist Uprisings, pp. 172-73. According to the Dutch the victims were either "accused of being in league with the government" or were killed as acts of "personal vendetta." See also Zed, "Pemberontakan Silungkang," pp. 136-42. Abdul Muluk Nasution describes those killed as being "anti the party" or merely "orang sana."

75 See, for example, telegrams from Padang dated, January 3 [no. 15], January 5 [no. 50], January 10 [No. 102], 1927, Mr. 28x/27, Mr. 29x/27, Mr. 58x/27. ARA.

76 FO Reports 1927, FO371/12696, signed J. Crosby, Consul General (Public Records Office, London).

77 To the Procureur-Generaal, August 30, 1927. 805 had been sentenced and 558 were awaiting trial. According to the "Overzicht der Onlusten," pp. 12-13, by January 12, 1927, 1,300 people had been rounded up in the Silungkang-Muara Klaban-Padang Sibusuk area, and around 200 had been arrested near Sijunjung, as well as smaller numbers in other areas.

78 Said, Pemberontakan Silungkang, pp. 33-36.Nasution, Pemberontakan Sarikat Rakyat, p. 123. The other two were M. Jusuf Sampono Kajo and Ibrahim Melawas. 
34 Audrey R. Kahin

continued in the Sawahlunto court until the middle of 1928. Those sentenced to less than two years were imprisoned in Sawahlunto itself, and the others sent to jails on Java, ${ }^{79}$ or exiled to Boven Digul. ${ }^{80}$

The rebellion's major impact was the greater excuse it offered the Dutch to crack down not only on Communist Party members, but on all political activity in the region. And it was also the precipitating factor in permanently splitting Tan Malaka from the Indonesian Communist Party which held him responsible for the rebellion's failure.

\section{Conclusions}

As can be seen from this account, the uprising in West Sumatra in the early days of 1927 , though bloody and traumatic, did not reflect either the strength or character of the major streams opposing Dutch rule in the region in the early decades of the twentieth century. A combination of the preemptive Dutch arrests of all their leading local opponents and Tan Malaka's explicit instruction to his many followers had destroyed any coherence among anti-Dutch forces. By the time the rebellion broke out, few of the prominent opposition leaders in the area remained free and active.

The effect of Tan Malaka's campaign against the rebellion was seen most clearly in Padang Panjang, where virtually all the major radical political leaders followed him in opposing it. Most of those loyal to him had fled the region during 1926, and the few who remained were arrested by the Dutch before the rebellion finally broke out. The leadership vacuum was exacerbated by the fact that most of Padang Panjang itself was physically destroyed by a major eruption of Mt. Merapi in June 1926. Consequently, the center of Communist support shifted to Padang and Silungkang, and as the more seasoned leaders in these two places were arrested, the initiative passed to lower-level activists with little political background, many of whom were preoccupied with settling personal scores.

As we have seen, opposition to Dutch rule was deep and widespread throughout much of West Sumatra and existed among most social, economic and religious groups. Communism was merely an additional strand, and was most successful when it was perceived as harmonizing with both the traditional societal order in West Sumatra and the teachings of Islam, while at the same time being an uncompromising opponent of Dutch rule. These criteria were embraced by Tan Malaka and the groups allied to him, and as a native son he had the greatest following in the area. Any attraction exerted by the other Communist groups tied more closely to the Javanese leadership depended to a large extent on the Communist Party being perceived as the most modern political organization in the region and the most effective agent for overturning colonial rule. The chaos of the actual revolutionary attempt undermined this reputation, and in the aftermath the only Communist stream that remained influential in West Sumatra for

\footnotetext{
79 See Nasution, Pemberontakan Sarikat Rakyat, pp. 125-26. He himself was sentenced to twelve years in jail, and with about seventy of his fellows was sent to Glodok jail, and later to Cipinang and Pamekasan (Madura), being released in 1938.

80 The prison camp at Boven Digul was established in 1927 to house Communist prisoners and their families. By March 1929, 2101 people were interned there (1124 men, 450 women and 527 children). These included Communist leaders from Batavia as well as those from Banten and West Sumatra. "Overzicht van den Inwendigen Politieken Toestand (April 1928-Mei 1929), Verslag van Bestuur en Staat van Nederlandsch-Indië, Suriname, en Curacao van 1929. (Landrukkerij, 1929-1930).
} 
the rest of the colonial period was the one tied to Tan Malaka, which continued to work with other socialist and religious groups in opposition to Dutch rule.

The Dutch appointed a commission of inquiry, headed by Dr. B. Schrieke, into the causes and effects of the uprising in West Sumatra. The commission, while criticizing individual Dutch policies, stressed the importance of internal factors of socioeconomic change in precipitating the rebellion. Some recent scholars have criticized the commission's findings, arguing that they underestimate the weight of the tax burden on West Sumatra's inhabitants and exaggerate the extent of social and economic change, while ignoring the economic impact of the Dutch government's alienation of forest land in some of the major centers where the rebellion broke out. ${ }^{81}$

The commission was at least partially correct in stressing the important effect of modern communications which did enable opponents of the Dutch to coordinate their activities. The railroad, in particular, provided a thread linking several of the rebellious areas, while railroad and mineworkers were among the rebellion's participants, though few of them were among the leaders. But most of the areas which the commission cited as subject to economic and social pressures conducive to encouraging the growth of communism were not in fact the areas where the anticolonial movement was strongest. The model of a stereotypical Minangkabau village which the commission portrayed as being upset by the modernizing forces being introduced into the area fitted ill with the actual places of greatest unrest, for they had very different social and economic structures. $^{82}$

The most important failing in the report, however, was the commission's attempt to portray rebellion against colonial rule as an aberration and the leaders of the opposition to Dutch governance as propelled by petty personal grievances, though this may have been the case with a few of the activists in Silungkang who finally went into rebellion. The commission described the principal leaders who had headed the opposition to colonial rule either as outside agitators or as emerging from "various groups of socially disillusioned persons." The leaders in Padang and Padang Panjang-Sutan Said Ali and Arif Fadlillah-were denigrated as "men who had wanted to become penghulu and had failed," while Sulaiman Labai, the leader of the anticolonial movement in Silungkang, was classified among "socially stranded people," and described merely as an ambitious man whose rice business had suffered

\footnotetext{
81 See Joel S. Kahn, "Peasant Political Consciousness in West Sumatra: A Reanalysis of the Communist Uprising of 1927," in History and Peasant Consciousness in South East Asia, ed. Andrew Turton and Shigeharu Tanabe (Osaka: Senri Ethnological Studies 13, 1984), pp. 293-325 and Akira Oki, "Economic Constraints, Social Change, and the Communist Uprising in West Sumatra (1926-1927)," in Change and Continuity in Minangkabau: Local, Regional and Historical Perspectives on West Sumatra, ed. Lynn L. Thomas and Franz von Benda-Beckmann (Athens: Ohio University Monographs in International Studies, 1985), pp. 207-34.

82 The actual social and cultural background of opposition to Dutch rule which preceded the outbreaks had little in common with Benda's and McVey's portrayal of the rebellions as "the well-nigh inescapable concomitant of economic and social forces generated by the collision of Western enterprise and colonial rule with the traditionally static societies of the Indonesian peasantry," wherein "would-be entrepreneurs and laborers ... were contracting out of the prescriptive adat of their ancestral environment." Communist Uprisings, pp.xx, xiii, xiv.
} 


\section{Audrey R. Kahin}

from creation of the railroad cooperative ${ }^{83}$ In assessing the validity of these insights it is perhaps worth pointing to the later history of Sulaiman Labai: this man whom Schrieke's commission characterized as opportunistic and ambitious, died on August 15, 1945 in Java's Ambarawa jail, where he was still serving the sentence imposed by the Dutch nearly twenty years earlier. ${ }^{84} \mathrm{He}$ had refused to be freed by the Japanese when they invaded but chose rather to continue his sentence under their occupation because he considered them no better than the Dutch in their colonization of Indonesia.

83 Benda and McVey, Communist Uprisings, p. 102; Schrieke, Indonesian Sociological Studies, pp. 132-33. The names of the people referred to were not included in this translation but appear in the original Rapport van de Commissie van Onderzoek, p. 125.

84 Said, Pemberontakan Silungkang, pp. 15, 37; Nasution, Pemberontakan Sarikat Rakyat, p. 229. 